\title{
Microbiological study of synbiotic fermented whey drink
}

\author{
TELLABATI V. MADHAVI AND R. K. SHAH
}

\begin{abstract}
The present investigation was carried out for formulation of functional probiotic/synbiotic whey drink with orange juice and also to study their microbiological. Whey based functional foods were in two different forms, A [whey + sugar @ $10 \%$ (w/v) + orange juice@ $10 \%(\mathrm{v} / \mathrm{v})], \mathrm{B}$ [A+ inulin@3\% (w/v)], and inoculated with probiotic culture Lb.rhamnosus @ 2.0\% v/v. The two blends (A and B) developed was subjected to microbiological, initially for the fresh (0 day) and upto 28 days of stipulated refrigerated storage at an interval of 7 days at $4 \pm 1^{\circ} \mathrm{C}$. During refrigerated storage for 28 days, Lactobacillus count remained well above $10^{8} \mathrm{cfu} / \mathrm{ml}$ for both the samples (A and B). The product had no yeast and mold count as well as coliform count throughout the refrigerated storage period. These products can surge ahead in market as appealing functional fermented whey drink for consumers as an alternative of carbonated soft drinks and give health benefits due to presence of probiotic culture, inulin, whey proteins and other whey constituents as well as orange fruit juice.
\end{abstract}

KEY WORDS : Synbiotic whey drink, Orange juice, Inulin, Microbiological, Lactobacillus count.

HOW TO CITE THIS PAPER : Madhavi, Tellabati V. and Shah, R.K. (2017). Microbiological study of synbiotic fermented whey drink. Res. J. Animal Hus. \& Dairy Sci., 8(1) : 1 -7 : DOI: 10.15740/HAS/RJAHDS/8.1/1-7.

Address for correspondence :

Tellabati V. Madhavi, Department of Dairy Microbiology, SMC College of Dairy Science, ANAND (GUJARAT) INDIA

Email : madhavismc@gmail.com

Associated Authors':

R.K. Shah, Department of Dairy Microbiology, SMC College of Dairy Science, ANAND (GUJARAT) INDIA 